ENTREPRENEURSHIP AND SUSTAINABILITY ISSUES

ISSN 2345-0282 (online) http://jssidoi.org/jesi/ 2019 Volume 7 Number 1 (September)

http://doi.org/10.9770/jesi.2019.7.1(31)

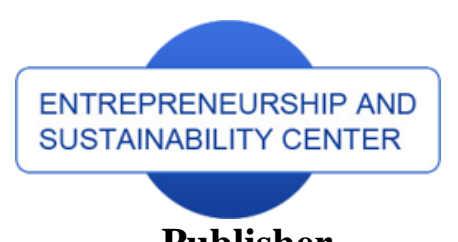

Publisher

http://jssidoi.org/esc/home

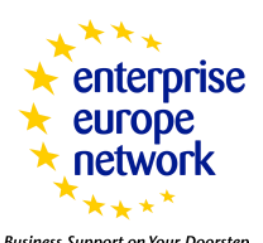

Business Support on Your Doorstep

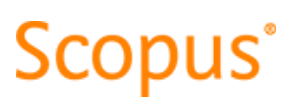

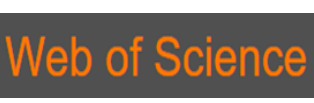

1) Clarivate

Analytics

\title{
REFINANCING AS AN ELEMENT OF CONTROL OVER INFLATION
}

\author{
Vladimir Maslennikov ${ }^{1}$, Dmitriy Korovin ${ }^{2}$, Oxana Afanasyeva ${ }^{3}$ \\ 1, 2, 3 Financial University under the Government of Russian Federation, 49 Leningradsky Pr., Moscow, 125993, Russia \\ E-mail: ${ }^{3}$ afanasyeva.o.n@yandex.ru
}

Received 14 February 2019; accepted 5 August 2019; published 30 September 2019

\begin{abstract}
The article is devoted to the problem of understanding the role and application of refinancing of bank systems as an instrument of monetary policy that can influence the parameters of the money market and the real sector of economy. The author analyses the differences in the impact of refinancing instruments of the central banks to economic indicators of 7 countries, namely: The USA, New Zealand, Norway, South Africa, China, Australia and India. The countries with different levels of economic development and with different banking systems, as well as refinancing mechanisms were chosen for the study. The paper focuses on the impact of changes in the refinancing rate on inflation, as well as on the index of consumer prices. The aspect of management is also considered. Common methods, based on econometrics, can determine the dependence, which does not coincide with the notion of "governance" in its broad sense. Thus, the purpose of the work is an attempt to define the properties of a monetary policy instrument as a control element, which - when changed - can predetermine a change in the controlled factor. This is an attempt to contribute to the discussion of the role of central banks refinancing in managing inflation. In order to obtain the results the new mathematical analysis tool was used that incorporates the aspects of methods that assess monetary policy's impact on macroeconomic indices, which are not recognized within standard econometric models. For this purpose, the authors used a function that determines the dependence of the coefficient from the correlation between the refinancing rate and the inflation rate based on the length of the period of time used for the temporary data used, the time of the beginning of this period and the time lag of inflation data in relation to these rates of refinancing. The authors suggest that the tool to influence inflation on has a deterministic quality (i.e., depending on the external factors it may lead to the opposite results) and has no stable time lag.
\end{abstract}

Keywords: monetary policy instrument; refinancing rate; inflation; consumer price index

Reference to this paper should be made as follows: Maslennikov, V.; Korovin, D.; Afanasyeva, O. 2019. Refinancing as an element of control over inflation, Entrepreneurship and Sustainability Issues 7(1): 438-453. http://doi.org/10.9770/jesi.2019.7.1(31)

JEL Classifications: G01, G15, G18, G21, G28

\section{Introduction}

Central bank interest rate policies are the most common instruments to impact on macroeconomics in the developed countries. This statement is confirmed by the studies conducted by Caporale et al. (2017), Papadamou et al. (2015), Wulandari (2012), Rubio (2016), Nucera et al. (2017), Horvath (2018), Popescu (2014), Tvaronavičienè (2018), Sanfilippo-Azofra et al. (2018). 


\section{ENTREPRENEURSHIP AND SUSTAINABILITY ISSUES}

ISSN 2345-0282 (online) http://jssidoi.org/jesi/

2019 Volume 7 Number 1 (September)

http://doi.org/10.9770/jesi.2019.7.1(31)

In most countries, Central Banks carry out refinancing, taking into account its functions at both the micro and macro levels. At the micro level, refinancing helps to adjust the bank portfolio in case of unexpected changes in the structure of assets and liabilities. At the macro level, refinancing helps to implement monetary policies to achieve its long-term objectives.

Refinancing ensures the impact on inflation, the availability of imported goods to the population, the price competitiveness of goods, the level of production of the economic sectors, the availability of bank loans, the rate of state duties, the penalties of banks and tax authorities, the flow of funds in the stock market (Vasiljeva, 2017).

Central banks are considered drivers in the fight against inflation. It is they who are responsible to maintain stability of the national currency unit.

Scientists of different economic directions study interrelations and impact of the monetary policy instruments, including the main one - the refinancing rate, and the most important economic indicators, such as inflation.

Different countries have their own refinancing rates; in case of their changes, Central Banks try to impact on the interest rates in the economy. In England, it is the interest rate on commercial banks' reserves in the accounts in the Bank of England; in Japan, it is the rate of the Bank of Japan for unsecured one-day loans; in the USA, it is the target level of the interest rate on interbank loans; in the euro zone, it is the minimum rate at the sale and repurchase agreement (REPO) auctions with the European Central Bank.

An important aspect of refinancing is that by modifying the parameters of this instrument, the Central Bank sends a signal to the private sector to change the current monetary policy targets. Moreover, the refinancing mechanism allows the authorities establishing the interest rate benchmark for the financial market. The Reserve Bank of India and the Bank of Russia are the most striking examples of the signaling function of refinancing: their refinancing rate is an indicator and not a financial instrument.

The refinancing mechanism has two drawbacks. Announcements about changes in the refinancing terms of the banking sector may be misinterpreted by market participants. Besides, frequent adjustments of the refinancing rate lead to excessive volatility of the money market rates, which results in unplanned changes in refinancing scopes and money supply. As a result, the effectiveness of monetary policy becomes lower.

The existing studies have shown that there are dependencies between the MP instruments and the macroeconomic factors. We believe that when analyzing the impact of any MP instruments on the factors, the notion of "management" is replaced by "dependence", which is determined by econometric methods. The purpose of this paper can be considered as to determine the aspects related to the managing impact of the MP instruments. Thus, the authors consider it especially relevant to reveal the properties of macroeconomic indicators management with the help of various instruments.

\section{Literature review}

According to Alvarez and Sánchez (2018), inflation targeting forecasts are based on the principle that, given the long-term inflation goal, a Central Bank's own inflation forecast is the best intermediate goal which allows the Central Bank conducting a monetary policy with the desired compromise between the inflation deviation from the goal and the output deviation from the potential. The reason why the inflation forecast is the best intermediate goal is that it includes all the relevant data available to the Central Bank. It means the awareness of politicians' preferences in respect of the compromise between the inflation deviation from the target and the production volume from the potential, as well as the Central Bank's position regarding the mechanism of monetary policy transmission. In this respect, accurate inflation forecasts of the Central Bank are important for effective monetary 


\section{ENTREPRENEURSHIP AND SUSTAINABILITY ISSUES}

ISSN 2345-0282 (online) http://jssidoi.org/jesi/

2019 Volume 7 Number 1 (September)

http://doi.org/10.9770/jesi.2019.7.1(31)

policy, since poor quality forecasts can lead to an inappropriate choice of a policy which can lead to the inflation deviating from the target and destabilizing the production output. This general interest in inflation forecasts has renewed in the recent years after the dramatic changes in the global economy during the Great Recession and its aftermath.

Bayar (2018) offers new approaches to evaluate the inflation targeting methods based on the Taylor rule. It points to the lack of accuracy of the previously proposed econometric methods and offers better instruments to increase the accuracy of the made forecasts.

Gobbi et al. (2018) apply Keynesian models based on the equations describing the Taylor rule for inflation targeting, the inflation lag in the Phillips Curve, as well as the equations of the inflation rate, the CB's refinancing rate and the "natural" interest rate corresponding to the overall economic equilibrium. All the models are econometric. The authors study their sensitivity depending on the parameters and point out possible conditions for their application in order to achieve more accurate forecasts.

Horvath et al. (2018) use a model where the bank's interest rate depends on the market rate and some extra charge, adding variables from the Kashyap and Stein models (1995) to describe the crisis period. At the same time, shocks, including inflation factors, are included in one variable Z. Studying the impact of the interest rate and the inflation is very problematic.

Popescu (2014) applies an econometric autoregressive model linking the refinancing rate at the moment $t$, the rate at the previous moment, the change in the GDP over $\mathrm{n}$ periods, the inflation rate at a given moment, and the real effective exchange rate fluctuations.

Papadamou et al. (2015) have presented PVAR, an econometric model which determines the nominal short-term interest rate dependence on four variables: the GDP logarithm in real prices, the consumer price index logarithm, the overnight rate of the money market, and the rates for bank loans.

Barnett et al. (2019) considered which inflation rate should be focused on the currency union and argued that the best monetary policy should be focused on the gap in production, the trade terms, the price index inflation rate, and the gap of the real marginal costs.

A number of authors are studying of the monetary policy of the Bank of Norway.

Kondratov (2012) highlights the effectiveness of the Norwegian MP in maintaining prices stable, which allows Norway to achieve better macroeconomic performance and higher living standards in the country. Inflation targeting is the basis for ensuring the price stability.

Fatas et al. (2006) present results showing that the inflation was lower in the inflation-targeted countries than in the non-inflation-targeted countries (the inflation was lower than in the money- or exchange rate-targeted countries).

A significant number of papers have been published on the impact of the Federal Reserve System's monetary policy on the inflation.

Taylor (1993): the article describes a Federal Reserve System's approach using the monetary policy rule which adjusts the short-term nominal interest rate in response to the inflation and output deviations. 


\section{ENTREPRENEURSHIP AND SUSTAINABILITY ISSUES}

ISSN 2345-0282 (online) http://jssidoi.org/jesi/

2019 Volume 7 Number 1 (September)

http://doi.org/10.9770/jesi.2019.7.1(31)

Taylor (2013): the author points to the need to consider more accurate today's models, since the USA's monetary policy has deviated from the well-known Taylor rule and the potential costs resulted from this deviation can be justified by international secondary effects.

Goodfriend (1991): interest rate smoothing operations facilitate the interaction between the Central Bank and market participants. The article mentions that the output and the prices do not respond to daily overnight rate fluctuations, but only to changes in the long-term interest rates.

Castelnuovo (2010): more and more studies show a strong link between the monetary policy and the (expected) inflation. The study examines the factors which determine the dynamics of inflation expectations in the USA and shows that the global indicators seem to have played a significant role until the mid-1980s, but later on they have been replaced by the US monetary policy factor.

Singh (2006) conducted a study on the impact of the monetary policy on the Indian inflation. He argued that the first stage of the financial sector reform was complete and that the macroeconomic indicators in terms of inflation and the interest rates were satisfactory and stable, as well as that the conditions allowed adopting the inflation targeting in India. Singh advocated for several issues to be addressed, namely the use of monetary instruments to control the inflation, the publication of a comprehensive report on the inflation, and the establishment of an Inflation Committee to ensure transparency of the work until the actual inflation targeting could have been adopted in India.

Analyzing the monetary policy of Japan, the authors made the following conclusions: Sims and Zha (2006): manipulation of the monetary base becomes the only possible option for the Bank of Japan as the interest rate approaches the zero bottom line. Its shocks seem to stimulate the economy, although they are not strong enough to cause inflationary pressure.

Okimoto (2019): the results showed that the devaluation of the Japanese yen resulted from the inflation targeting policies introduced by the Bank of Japan and played an important role in the significant inflation growth in 2013.

A number of researchers analyze the impact of the Chinese monetary policy on the inflation.

Fan et al. (2011): the authors study the response of the Chinese monetary policy in terms of the money supply and the interest rates to the economic conditions and the effectiveness of these policies in achieving the goals to stimulate the economic growth and control the inflation. The quarterly results for 1992-2009 show that the money supply rule has some impact on future inflation and the real production output, but the interest rate rule does not affect the expected inflation and the real output.

Koch (2007): despite significant changes in the Chinese monetary policy over the past two decades, loan granting has always played a crucial role, and the $\mathrm{PBC}$ has increasingly relied on interest rates to achieve its policy goals in the recent years.

Liu (2018): the interest rate has been a key monetary policy issue. At the same time, this issue has become very complex and relevant for the Chinese decision-makers regarding the country's economy in the shadow of the China-US trade war. The study shows that macroeconomic conditions affect credit rates.

When studying the impact of the monetary policy on the South African inflation, the authors noted a number of opinions. 


\section{ENTREPRENEURSHIP AND SUSTAINABILITY ISSUES}

ISSN 2345-0282 (online) http://jssidoi.org/jesi/ 2019 Volume 7 Number 1 (September) http://doi.org/10.9770/jesi.2019.7.1(31)

Woglom (2005): when discussing how the inflation targeting introduced in 2000 impacted the monetary policy in South Africa, the researcher points out that South African Reserve Bank's response to the changed real value of its currency has not been transparent and, therefore, is a source of confusion.

Taylor (2001): exchange rate stabilization can help stabilize production and reduce the inflation to the target level. When financial markets are poorly developed, for example, in case of emerging markets, Central Banks play a crucial role in managing the economic agents' expectations.

The studies related to the interaction between monetary policies and inflation expectations arouse interest. For example, Gobbi et al. (2018) suggest that the agents form expectations in terms of a probabilistic belief that the economy can go from normal to depressed. The authors make two conclusions. First, when facing shocks, if the inflation expectations "fall faster" than the political rate and the zero limit is reached without any adjustment of the impact, the system enters a new stable state - the "new normal", with constant negative gaps. Second, a more aggressive monetary policy is ineffective both at the zero lower limit and above it when the impact is large and/or when the inflation expectations are rather high.

Buono and Formai (2018) have explored the scope of pegging of the inflation expectations are in the advanced economies and found that, following the financial crisis, the expectations were firmly pegged to the goals in the USA and, to a lesser extent, in the United Kingdom. In the euro zone, the expectations were cancelled soon after the crisis and again, starting from 2014. In Japan, the removal of pegging has been more common throughout the entire sampling period.

\section{Study methods}

To determine which monetary policy instruments influence the macroeconomic indicators, the following approach is applied.

Essentially, it is a correlation analysis method.

Here are the critical remarks of the known approaches.

In the works given in the References, in order to prove the influence of the MP instruments on the macroeconomic indicators, the authors usually use an economic approach.

This means plotting the function

$$
\mathrm{Y}=\mathrm{f}\left(\mathrm{X}, \mathrm{z}_{1}, \mathrm{z}_{2}, \ldots \mathrm{z}_{\mathrm{n}}\right)
$$

where $\mathrm{Y}$ - the studied macroeconomic indicator, $\mathrm{X}$ - the monetary policy instrument considered as controlling parameter, $\mathrm{Z}_{1}, \mathrm{Z}_{2}, \ldots, \mathrm{Z}_{\mathrm{n}}-\mathrm{a}$ set of factors allowing an accurate forecast of $\mathrm{Y}$.

In case of successful modeling, the authors point out the presence of dependence of $Y$ on the controlling variable $\mathrm{X}$ under conditions determined by the values of $\mathrm{z}_{1}, \mathrm{z}_{2}, \ldots, \mathrm{z}_{\mathrm{n}}$.

However, the presence of factors $\mathrm{z}_{1}, \mathrm{z}_{2}, \ldots, \mathrm{z}_{\mathrm{n}}$ indicates that the variable $\mathrm{X}$ may not be a controlling factor. Let's say that the variable $\mathrm{X}$ is a control factor, if its changes in some direction leads to a change in the controlled parameter in the previously defined direction.

The Corr function is calculated as 


$$
\begin{gathered}
\operatorname{Corr}\left(\left\{\mathrm{x}_{\mathrm{t}}, \mathrm{x}_{\mathrm{t}+1 / 12}, \mathrm{x}_{\mathrm{t}+2 / 12}, \ldots, \mathrm{x}_{\mathrm{t}+\Delta}\right\},\left\{\mathrm{y}_{\mathrm{t}+\mathrm{s}}, \mathrm{y}_{\mathrm{t}}+1 / 12+\mathrm{s}, \mathrm{y}_{\mathrm{t}+2 / 12+\mathrm{s}}, \ldots, \mathrm{y}_{\mathrm{t}+\Delta+\mathrm{s}}\right\}\right)= \\
\left.=\operatorname{Cov}\left(\mathrm{X}_{\Delta}(\mathrm{t}), \mathrm{Y}_{\Delta, \mathrm{s}}(\mathrm{t})\right) /\left(\operatorname{VarX}_{\Delta}(\mathrm{t}) \cdot \operatorname{VarY}_{\Delta, \mathrm{s}}(\mathrm{t})\right)\right)^{-1 / 2} \\
\operatorname{Cov}\left(\mathrm{X}_{\Delta}(\mathrm{t}), \mathrm{Y}_{\Delta, \mathrm{s}}(\mathrm{t})\right)=\left(\mathrm{x}_{\mathrm{t}} \cdot \mathrm{y}_{\mathrm{t}+\mathrm{s}}+\mathrm{x}_{\mathrm{t}+1 / 12} \cdot \mathrm{y}_{\mathrm{t}+1 / 12}+\ldots+\mathrm{x}_{\mathrm{t}+\Delta} \cdot \mathrm{y}_{\mathrm{t}+\Delta+\mathrm{s}}\right) /(12 \Delta) \mathrm{EX}_{\Delta}(\mathrm{t}) \cdot \mathrm{EV}_{\Delta, \mathrm{s}}(\mathrm{t}) \\
\operatorname{VarX}_{\Delta}(\mathrm{t})=\left(\left(\mathrm{x}_{\mathrm{t}}-\mathrm{EX}_{\Delta}(\mathrm{t})\right)^{2}+\left(\mathrm{x}_{\mathrm{t}+1 / 12}-\mathrm{EX}_{\Delta}(\mathrm{t})\right)^{2}+\ldots+\left(\mathrm{x}_{\mathrm{t}+\Delta}-\mathrm{EX}_{\Delta}(\mathrm{t})\right)^{2}\right) /(12 \Delta-1) \\
\operatorname{VarY}_{\Delta, \mathrm{s}}(\mathrm{t})=\left(\left(\mathrm{y}_{\mathrm{t}+\mathrm{s}}-\mathrm{EY}_{\Delta, \mathrm{s}}(\mathrm{t})\right)^{2}+\left(\mathrm{y}_{\mathrm{t}+1 / 12+\mathrm{s}}-\mathrm{EY}_{\Delta, \mathrm{s}}(\mathrm{t})\right)^{2}+\ldots+\left(\mathrm{y}_{\mathrm{t}+\Delta+\mathrm{s}}-\mathrm{EY}_{\Delta, \mathrm{s}}(\mathrm{t})\right)^{2}\right) /(12 \Delta-1) \\
\mathrm{EX}_{\Delta}(\mathrm{t})=\left(\mathrm{x}_{\mathrm{t}}+\mathrm{x}_{\mathrm{t}+1 / 12}+\ldots+\mathrm{x}_{\mathrm{t}+\Delta}\right) /(12 \Delta) \\
\operatorname{EY}_{\Delta, \mathrm{s}}(\mathrm{t})=\left(\mathrm{y}_{\mathrm{t}+\mathrm{s}}+\mathrm{y}_{\mathrm{t}+1 / 12+\mathrm{s}}+\ldots+\mathrm{y}_{\mathrm{t}+\Delta+\mathrm{s}}\right) /(12 \Delta)
\end{gathered}
$$

Interpretation of the results is preceded by the selection of the function, corresponding most to the reality, depending on a time lag, i.e. the time of delay of the MP instrument impact on the macroeconomic indicator. It is logical to consider the values of $\mathrm{s}$ equal to $0,1, \ldots, 12$. The selected range of three years covers 36 values of time moments, when the functions $\mathrm{F}=\mathrm{F}(\mathrm{t}, 3, \mathrm{~s}), \mathrm{s}=0,1, \ldots, 12$ are calculated. At these moments, the maximum $\mathrm{s}$ value is compared to 13 , the rest - to 0. Comparison of the sums of these values at fixed s for different $s$ gives us the most adequate time lag. (If there are several lags with equal sums, we carry out a similar procedure for these lags, but compare the elements following after the maximum ones, etc.). Thus, the function $\mathrm{F}=\mathrm{F}(\mathrm{t}, 3, \mathrm{~s})$ determines the best estimation of the impact of the factor $\mathrm{X}$ on the factor $\mathrm{Y}$, taking into account the time lag, as well as the impact character within $\Delta=3$ years (the longer period leads to dilution - the correlations values become essentially smaller in absolute values, than at $\Delta=3$; at smaller values of $\Delta$ the function often becomes oscillating, i.e. essentially depending on insignificant (in terms of economy) perturbations).

When interpreting the $\mathrm{F}$ function, it should be noted that if the $\mathrm{F}$ values are within the ranges close to the values of +1 or -1 , the studied macroeconomic indicator changes, though the control indicator does not change. It does not indicate the evidence that this MP indicator is management.

On the other hand, if changes in the MP indicator does not result in changes of the trend of the macroeconomic indicator, and the $\mathrm{F}$ values are within the ranges close to the values of +1 or -1 , we believe that the conclusion on "manageability" is not correct, as well.

Plotting of the dependencies lead to the following results.

The presence of dependence is determined by the proved, if the plotted correlation chart $\mathrm{F}=\mathrm{F}(\mathrm{t}, \Delta, \mathrm{s})$ lies close to one or minus one, and the functions are not constant within the corresponding intervals on the MP instrument charts and the indicator chart.

Following the rules of regression analysis, we can determine the impact as positive (the growth of the value $\mathrm{X}$ results in the growth of the value $\mathrm{Y}$, while the decrease of the value $\mathrm{X}$ leads to the decrease of the value $\mathrm{Y}$ ), or negative (the growth of the value $\mathrm{X}$ simulates the decrease of the value $\mathrm{Y}$, the decrease of the value $\mathrm{X}$ results in the growth of the value $\mathrm{Y}$ ).

The situation when the chart $\mathrm{F}$ oscillates with a high amplitude in the band containing both the set in the negative and in the positive semi-plane is indisputably interpreted. In this case, the variable $\mathrm{X}$ is not a controlling variable. Oscillation means that management can lead to both expected and unexpected results.

The chart which at some values of $\mathrm{t}<\mathrm{T}_{0}$ lies close 1 , and at $\mathrm{t}>\mathrm{T}_{0}$ - close to -1 can be interpreted as being manageable in one way at $t<T_{0}$, being manageable in a completely different way at $t>T_{0}$. (This is also true if the chart moves from $\mathrm{Y}<0$ to $\mathrm{Y}>0$ ). 
If the chart lies close to 0 , the values do not correlate, the management is not observable or significant.

The preliminary data analysis was carried out according to the following plan.

At the initial stage, further analysis was allowed for the countries with the absolute value of the correlation between the refinancing rate and the inflationary processes indications equal to at least 0.4 within the period from January 2000 to December 2017. The financial systems of Australia (1), India (2), New Zealand (3), Norway (4), USA (5), China (6), and South Africa (7) were selected.

At the following stage, the below-mentioned functions were plotted for each country

$$
\mathrm{F}_{\mathrm{i}}=\mathrm{F}_{\mathrm{i}}(\mathrm{t}, 3, \mathrm{~s}) \text {, }
$$

where $\mathrm{i}=1, \ldots, 7$ - the country's number, $\mathrm{s}=0,1 / 12,2 / 12, \ldots 12 / 12$ - the monthly lag, $\mathrm{t}$ - the time points by month, from January 2000 to December 2014, plus the months of the time lag, determined by the value s.

According to the rule given above, the most significant time lag was selected for each country, $\mathrm{s}_{\mathrm{i}}$. The obtained dependence was analyzed.

\section{Source data}

The following sources were used for the analysis:

The official websites of the US Federal Reserve System, the Reserve Bank of New Zealand, the Reserve Bank of India, the Reserve Bank of South Africa, the Bank of Norway, the Reserve Bank of Australia, the People's Bank of China;

Thomson Reuters Database (Countrycard: economics);

Thomson Reuters Database (Datastream);

The website of the International Monetary Fund.

The data were selected from January 1, 2000, to December 31, 2017. The frequency of data - monthly data. Missed data were completed by repeating the previous value in time.

\section{Findings}

The type of the identified dependencies with interpretation of the results is specified in Table 1.

Table 1. Interpretation of the charts

\begin{tabular}{|l|l|l|}
\hline Title & Lag si & Interpretation \\
\hline $\begin{array}{l}\text { Fig. 1. Key rate correlation (\%) with a } \\
\text { GDP deflator (\%) in South Africa }\end{array}$ & 4 & $\begin{array}{l}\text { There are three waves of oscillation, and } \\
\text { from June, 2002 to October, 2005 the } \\
\text { relationship is steadily negative. The } \\
\text { management character significantly } \\
\text { depends on additional conditions. The } \\
\text { rate cannot be used as the only } \\
\text { management parameter }\end{array}$ \\
\hline $\begin{array}{l}\text { Fig. 2. Base rate correlation (\%) with } \\
\text { CPI }(\%) \text { in New Zealand }\end{array}$ & 3 & $\begin{array}{l}\text { There are two waves of oscillation, and } \\
\text { from June, 2007 to December, 2010 the }\end{array}$ \\
\hline
\end{tabular}


ENTREPRENEURSHIP AND SUSTAINABILITY ISSUES

ISSN 2345-0282 (online) http://jssidoi.org/jesi/ 2019 Volume 7 Number 1 (September)

http://doi.org/10.9770/jesi.2019.7.1(31)

\begin{tabular}{|c|c|c|}
\hline & & $\begin{array}{l}\text { relationship is steadily positive. From } \\
\text { July, } 2007 \text { to October, } 2010 \text { the } \\
\text { relationship is unsteadily negative. The } \\
\text { management character significantly } \\
\text { depends on additional conditions. The } \\
\text { rate cannot be used as the only } \\
\text { management parameter }\end{array}$ \\
\hline $\begin{array}{l}\text { Fig. 3. FRS rate correlation (\%) with } \\
\text { CPI }(\%) \text { in the USA }\end{array}$ & 3 & $\begin{array}{l}\text { There are two waves of oscillation. From } \\
\text { July, } 2002 \text { to May, 2005, the relationship } \\
\text { is steadily positive, while from } \\
\text { December, } 2005 \text { to June, } 2012 \text { it is } \\
\text { negative. Obviously, the external } \\
\text { environment determines the impact } \\
\text { character. The rate cannot be used as the } \\
\text { only management parameter }\end{array}$ \\
\hline $\begin{array}{l}\text { Fig. 4. Refinancing rate correlation }(\%) \\
\text { with CPI }(\%) \text { in Norway }\end{array}$ & 5 & $\begin{array}{l}\text { There are two periods }- \text { positive } \\
\text { dependence from September, } 2003 \text { to } \\
\text { May, 2006; from this moment to } 2014 \\
\text { the dependence is negative with } \\
\text { significant disturbances (deviation from } \\
\text { the trend) in May, 2009. The rate cannot } \\
\text { be used as the only management } \\
\text { parameter. The dependence character is } \\
\text { similar the indicator for Australia }\end{array}$ \\
\hline $\begin{array}{l}\text { Fig. 5. Key rate correlation (\%) with CPI } \\
(\%) \text { in Australia }\end{array}$ & 5 & $\begin{array}{l}\text { There are two periods }- \text { positive } \\
\text { dependence from June, 2001 to } \\
\text { December, 2005; from this moment to } \\
2014 \text { the dependence is negative with } \\
\text { significant disturbances (deviation from } \\
\text { the trend) in May, 2009. The rate cannot } \\
\text { be used as the only management } \\
\text { parameter. The dependence character is } \\
\text { similar the indicator for Norway }\end{array}$ \\
\hline $\begin{array}{l}\text { Fig. 6. Discount rate correlation (\%) } \\
\text { with CPI }(\%) \text { in India }\end{array}$ & 4 & $\begin{array}{l}\text { In addition to the pre-crisis time interval } \\
\text { from February, } 2003 \text { to May, } 2007 \text {, the } \\
\text { dependence is steadily negative. The rate } \\
\text { is may be used, taking into account the } \\
\text { external environment }\end{array}$ \\
\hline $\begin{array}{l}\text { Fig. } 7 \text {. Refinancing rate correlation (\%) } \\
\text { with CPI }(\%) \text { in China }\end{array}$ & 2 & $\begin{array}{l}\text { Except for the "positive" period from } \\
\text { September, } 2004 \text { to May, 2008, the } \\
\text { dependence is oscillating that doesn't } \\
\text { allow using the rate as a management } \\
\text { instrument. }\end{array}$ \\
\hline
\end{tabular}




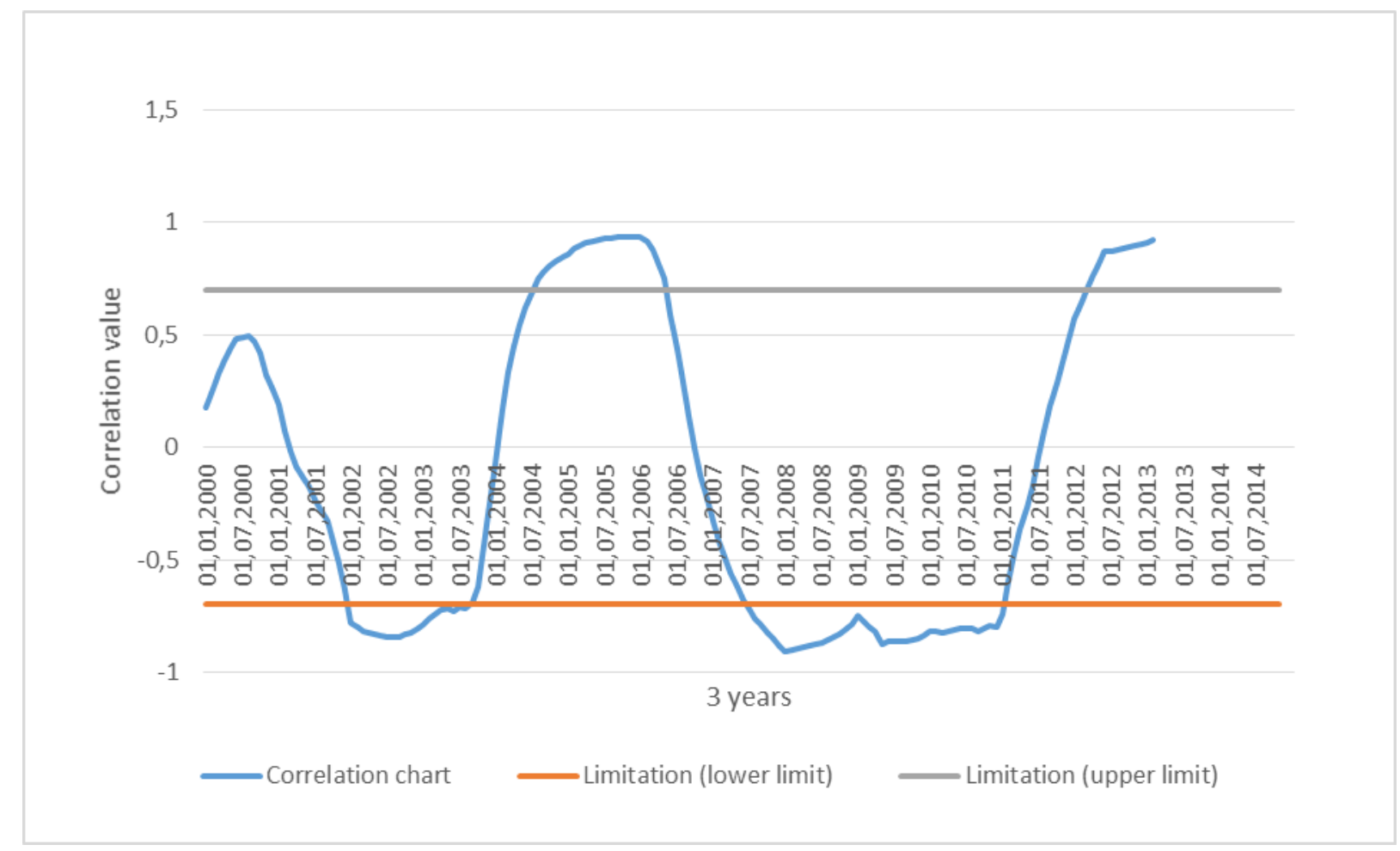

Fig. 1. Key rate correlation (\%) with a GDP deflator (\%) in South Africa 


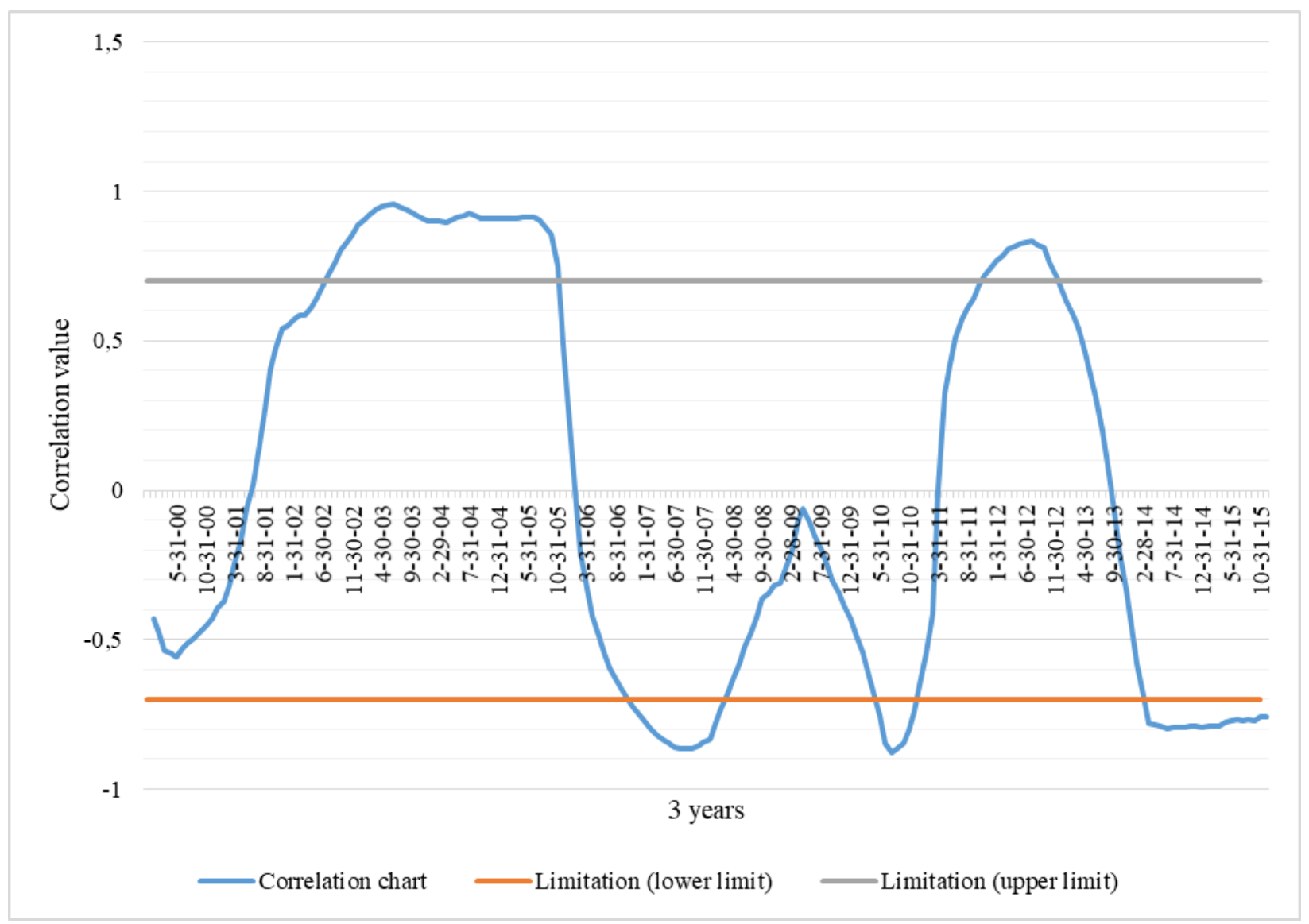

Fig. 2. Base rate correlation (\%) with CPI (\%) in New Zealand

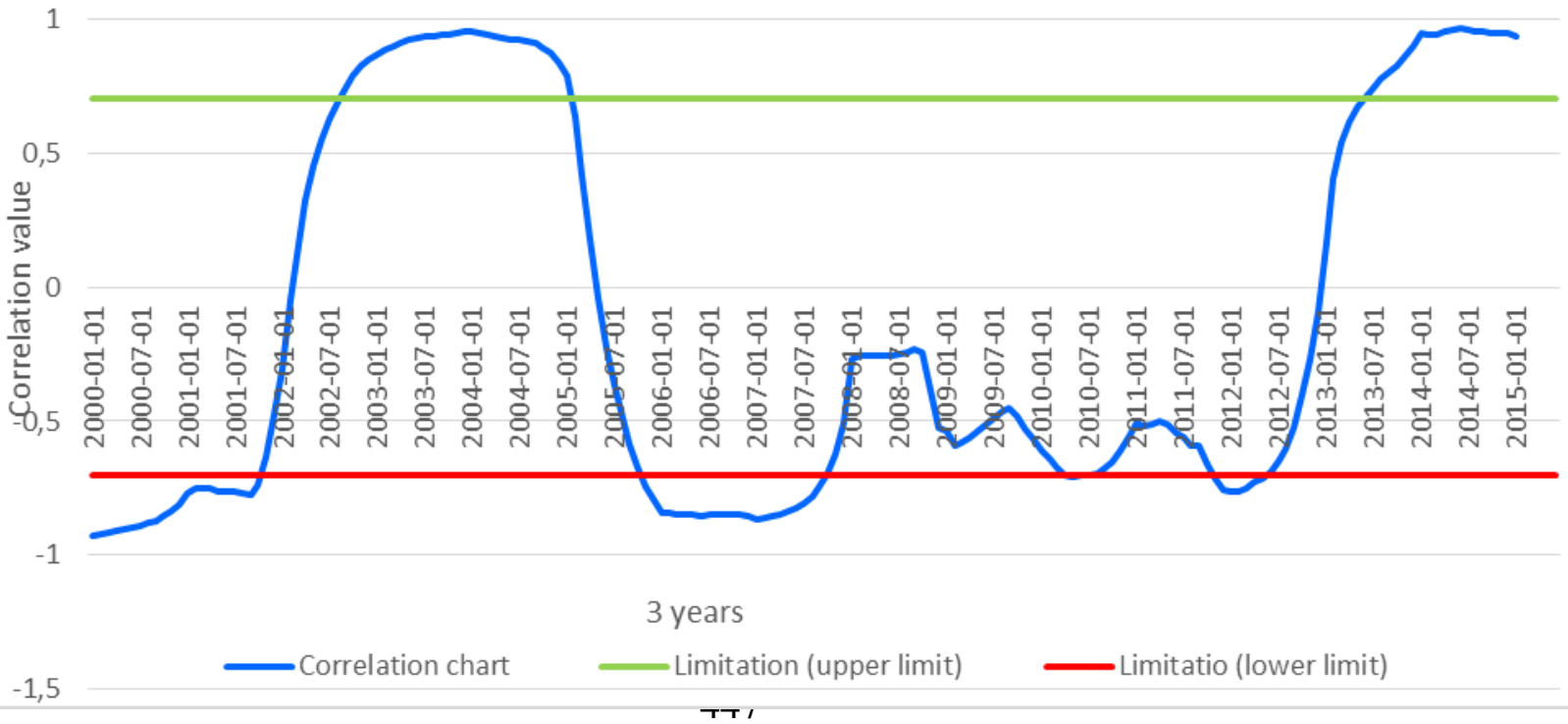


Fig. 3. FRS rate correlation (\%) with CPI (\%) in the USA

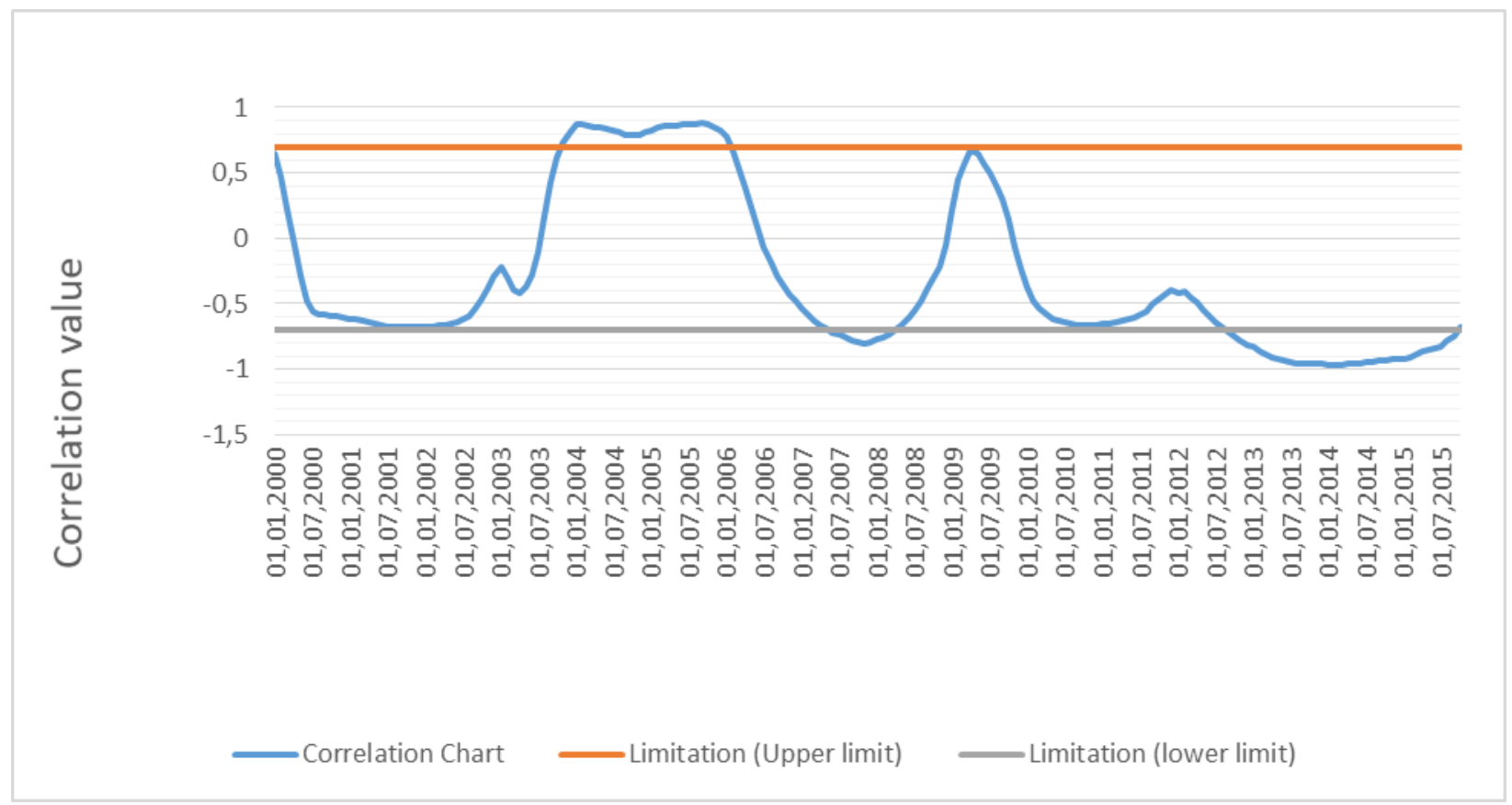

Fig. 4. Refinancing rate correlation (\%) with CPI (\%) in Norway

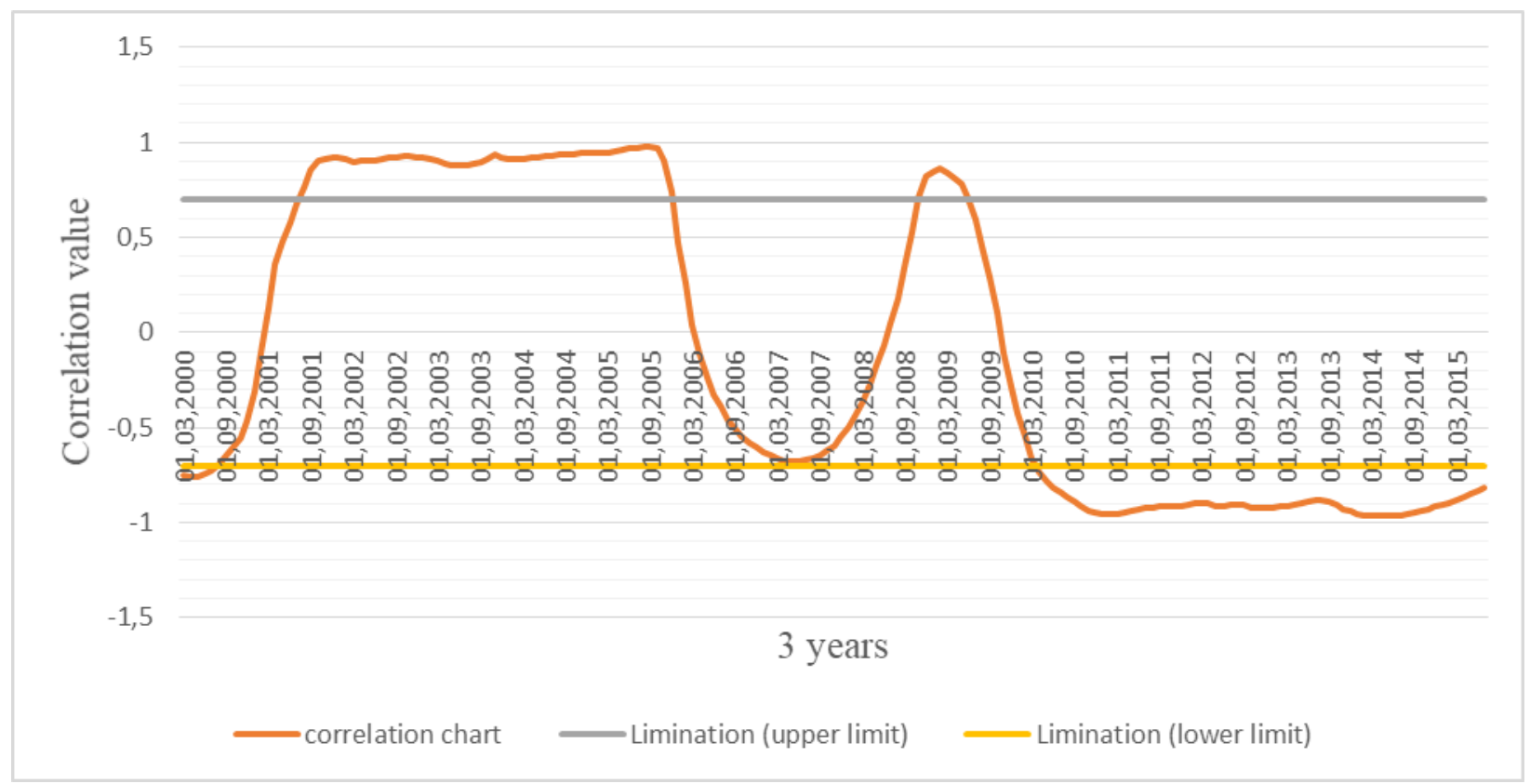

Fig. 5. Key rate correlation (\%) with CPI (\%) in Australia 


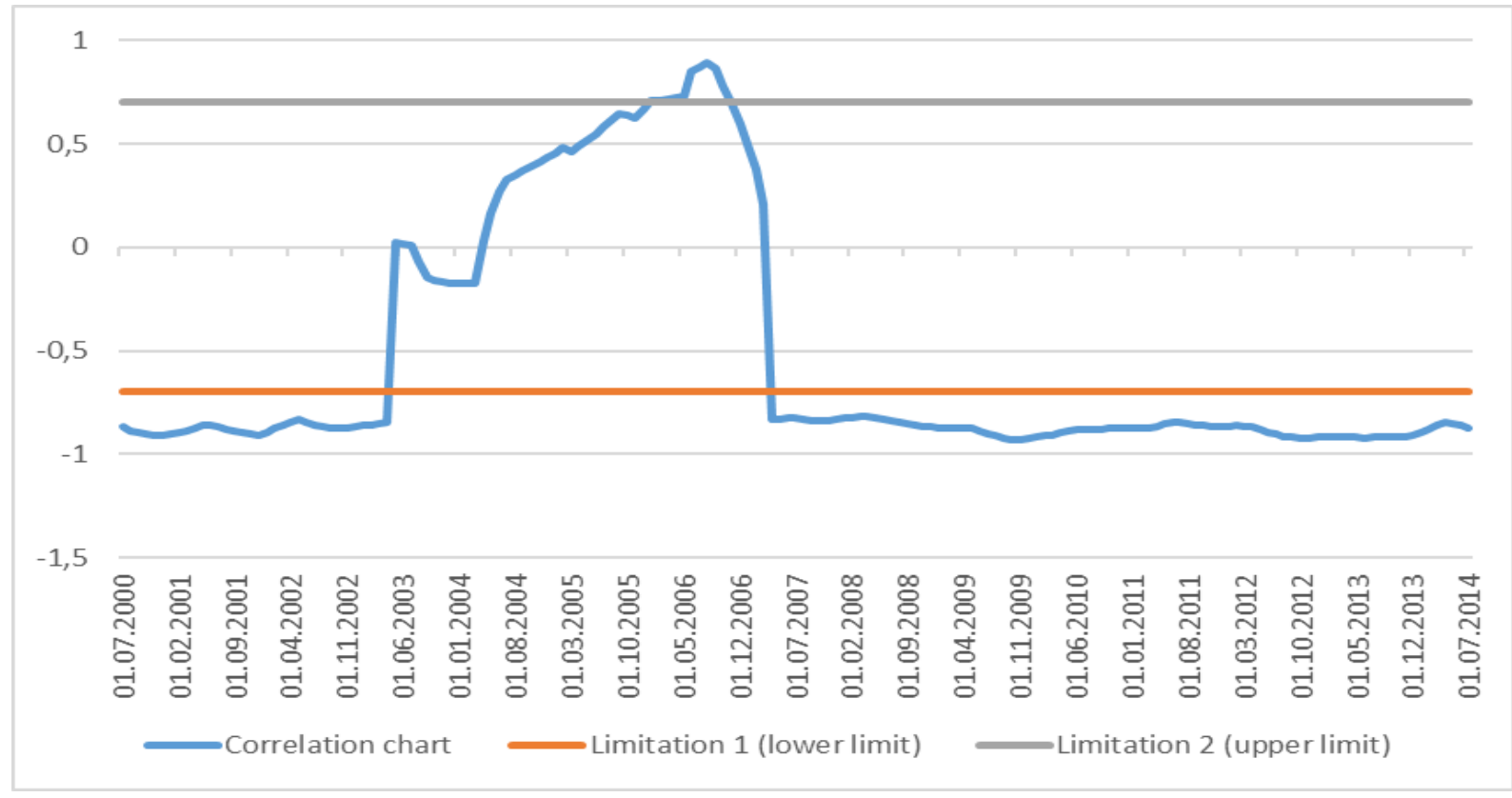

Fig. 6. Discount rate correlation (\%) with CPI (\%) in India

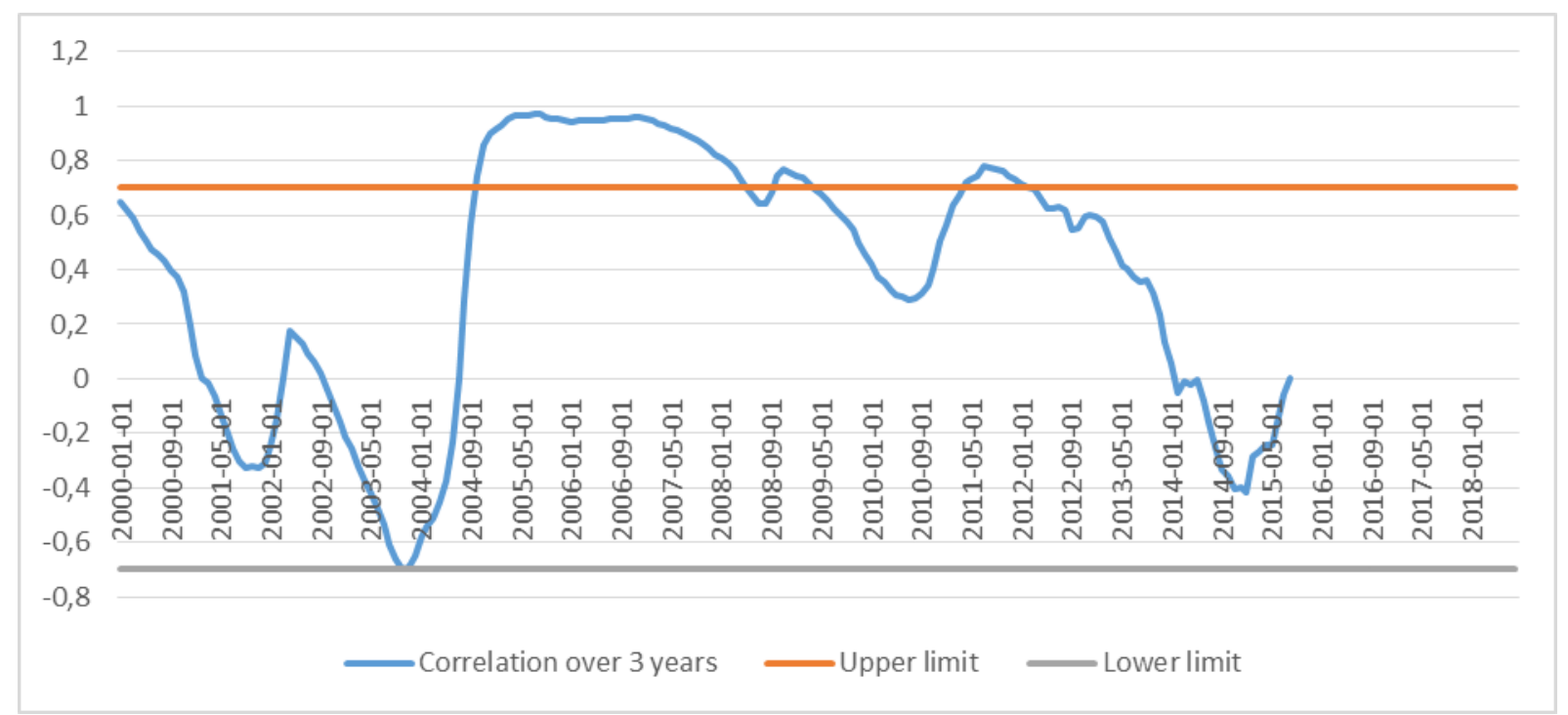

Fig. 7. Refinancing rate correlation (\%) with CPI (\%) in China

In the periods of economic development there is a high positive relationship between the rate and the CPI, since the Reserve Bank of New Zealand gradually increased the lending rate in order to contain the inflation, due to the increase in the consumer prices index accompanying the economic growth.

The characteristics of the refinancing rate and the inflation in Norway, South Africa and New Zealand are quite similar, indicating some typology of possible management. 


\section{ENTREPRENEURSHIP AND SUSTAINABILITY ISSUES}

ISSN 2345-0282 (online) http://jssidoi.org/jesi/

2019 Volume 7 Number 1 (September)

http://doi.org/10.9770/jesi.2019.7.1(31)

Turning to the Norwegian experience, Kondratov (2012) points out that: "Inflation targeting is the basis for ensuring stable prices; regulation of the monetary sphere is flexible, it is carried out based on the international experience and specifics of the existing transmission mechanism".

In the USA, the FRS rate had a strong direct correlation with the CPI, as well as with the inflation rate from July, 2002 to May, 2005. This is due to the fact that, until then, there has been a dramatic decline in the growth rate compared to the previous year and they were out of control of the monetary policy, and the Federal Reserve System regulates the rate to change the economic situation in the country. There has also been a strong dependence on the CPI and the inflation rate since the beginning of 2013 until now.

Goodfriend (1991) believes that: "The interest rate smoothing operations facilitate the interaction between the Central Bank and market participants. The article mentions that the output and the prices do not respond to daily fluctuations of the overnight rate, but only to changes in the long-term interest rates".

In Australia, the inverse relationship between the key rate and the CPI results from the same law, as in the case of the GDP, i.e. a decrease in the money inflow into the economy due to increased key rates.

The periods from 2000 to 2003 and from 2007 to 2014 in India are characterized by a high negative correlation due to the fact that under conditions of economic slowdown, the refinancing rate increases, which leads to a decrease in the CPI.

It is possible to confirm what Singh (2006) states: "The first stage of the financial sector reform was complete and that the macroeconomic indicators in terms of inflation and the interest rates were satisfactory and stable, as well as that the conditions allowed adopting the inflation targeting in India. Singh advocated for several issues to be addressed, namely the use of monetary instruments to control the inflation, the publication of a comprehensive report on the inflation, and the establishment of an Inflation Committee to ensure transparency of the work until the actual inflation targeting could have been adopted in India".

Since the Chinese money supply grew from $14 \%$ in 2000 to $20 \%$ in 2003, the period of 2000-2003, the industrial production growth rates recovered up to $16.2 \%$ in 2003, and the consumer price index began to grow steadily, which can be seen in the chart - the correlation level has significantly increased.

\section{Conclusions}

The study revealed a twofold dependence between the changes in the inflation and the changes in the refinancing rate.

Three types of impact were identified.

The first type (USA, New Zealand, Norway, South Africa, Australia) is characterized by two stages of impact. The first, pre-crisis included positive influence, the rate growth determined the inflation growth; the second stage, starting from about 2006 - a negative dependence. If in the USA and South Africa the dependence was stable during this period of time, and since 2012 it has become positive again, New Zealand, Norway, and Australia are characterized by the disturbances of 2009 with a stable negative dependence up to 2014 (2017, as a 3-year period is considered).

India is the second type. It is characterized by a stage of positive influence in the pre-crisis period and further stable negative relationship, not subject to disturbances. 


\section{ENTREPRENEURSHIP AND SUSTAINABILITY ISSUES}

ISSN 2345-0282 (online) http://jssidoi.org/jesi/ 2019 Volume 7 Number 1 (September) http://doi.org/10.9770/jesi.2019.7.1(31)

An unpredictable Chinese indication is the third type. At the same time, China has been selected, and it may mislead the study, which is conducted without taking into account the dynamics of changes in the correlation.

The refinancing rate responds to the inflation with different lags.

Tightening of the monetary policy gives effect as a reduction of inflation only if this instrument is used after the stabilization period. In case of frequent application within a short period of time, the consequences may be unpredictable.

There is a feedback at some time intervals: the growth of the refinancing rate outpaces the inflation, i.e. leads to the inflation growth.

The inflation expectations, as a powerful factor of the price growth, arouse from the production and the sale of goods. As a consequence, it limits the role of monetary methods of the inflation management.

Under conditions of the financial and economic crises of 2008-2009, during the recession, and then the decline in prices (deflation), the Central Banks of a number of countries lowered the refinancing rate. The consequences were not obvious.

The method presented by the authors is new. It allows studying not the dependence of factors, as in the econometric studies, determining the quality of management of the MP instruments of the values, which are significant macroeconomic characteristics, set as targets.

The limitations of the method are that only variations of one MP instrument are considered as management. The authors will demonstrate the results of the analysis of the possibility to manage several MP instruments with key macroeconomic factors in the following papers.

\section{References}

Alvarez, L. J.; Sanchez, I. 2018. Inflation projections for monetary policy decision making, Journal of Policy Modeling. https://doi.org/10.1016/j.jpolmod.2018.09.005

Barnett, W. A.; Wang, C.; Wang, X.; Wu, L. 2019. What inflation measure should a currency union target?, Journal of Macroeconomics 59(C): 123-139. http://dx.doi.org/10.1016/j.jmacro.2018.11.006

Bayar, O. 2018. Weak instruments and estimated monetary policy rules, Journal of Macroeconomics 58(C): 308-317. http://dx.doi.org/10.1016/j.jmacro.2018.10.004

Buono, I.; Formai, S. 2018. New evidence on the evolution of the anchoring of inflation expectations, Journal of Macroeconomics 57(C): 39-54. http://dx.doi.org/10.1016/j.jmacro.2018.04.003

Caporale, G. M.; Carcel, H.; Gil-Alana, L. 2017. Central bank policy rates: Are they cointegrated?, International Economics 152: 116-123. https://doi.org/10.1016/j.inteco.2017.06.001

Castelnuovo, E. 2010. Tracking U.S. inflation expectations with domestic and global indicators, Journal of International Money and Finance 29(7): 1340-1356. https://doi.org/10.1016/j.jimonfin.2010.03.006

Fan, L.; Yu, Y; Zhang C. 2011. An empirical evaluation of China's monetary policies, Journal of Macroeconomics 33(2): 358-371. https://doi.org/10.1016/j.jmacro.2010.11.003

Fatas, A.; Mihov, I.; Rose, A. K. 2006. Quantitative goals for monetary policy. National Bureau of Economic Research Working Paper No. 10846. Retrieved from https://www.nber.org/papers/w10846 


\section{ENTREPRENEURSHIP AND SUSTAINABILITY ISSUES}

ISSN 2345-0282 (online) http://jssidoi.org/jesi/ 2019 Volume 7 Number 1 (September) http://doi.org/10.9770/jesi.2019.7.1(31)

Gobbi, L.; Mazzocchi, R.; Tamborin, R. 2018. Monetary policy, de-anchoring of inflation expectations, and the "new normal", Journal of Macroeconomics. https://doi.org/10.1016/j.jmacro.2018.10.006

Goodfriend, M. 1991. Interest rates and the conduct of monetary policy, Carnegie-Rochester Conference Series on Public Policy 34: 7-30. https://doi.org/10.1016/0167-2231(91)90002-M

Horvath, R.; Kotlebova, J.; Siranova, M. 2018. Interest rate pass-through in the euro area: Financial fragmentation, balance sheet policies and negative rates, Journal of Financial Stability 36: 12-21. https://doi.org/10.1016/j.jfs.2018.02.003

Kashyap, A. K.; Stein, J. C. 1995. The impact of monetary policy on bank balance sheets, Carnegie-Rochester Conference Series on Public Policy 42: 151-195. https://doi.org/10.1016/0167-2231(95)00032-u

Koch, E. 2007. The monetary policy transmission mechanism in China, in Challenges at the Bank for International Settlements. Berlin: Springer, 321-327.

Kondratov, D. I. 2012. Actual aspects of monetary policy in Norway, Forecast Issues 1: 129-151.

Liu, K. 2018. Chinese manufacturing in the shadow of the China-US Trade War, Economic Affairs 38(3): 307-324. http://dx.doi.org/10.1111/ecaf.12308

Nucera, F.; Lucas, A.; Schaumburg, J.; Schwaab, B. 2017. Do negative interest rates make bank less safe?, Economics Letters 159: 112115. http://dx.doi.org/10.1016/j.econlet.2017.07.014

Okimoto, T. 2019. Trend inflation and monetary policy regimes in Japan, Journal of International Money and Finance 92: 137-152. http://dx.doi.org/10.1016/j.jimonfin.2018.12.008

Papadamou, S.; Sidiropoulos, M.; Spyromitros, E. 2015. Central bank transparency and the interest rate channel: Evidence from emerging economies, Economic Modelling 48: 167-174. http://dx.doi.org/10.1016/j.econmod.2014.10.016

Popescu, I. V. 2014. Analysis of the behavior of central banks in setting interest rates. The case of Central and Eastern European countries, Procedia Economics and Finance 15: 1113-1121. http://dx.doi.org/10.1016/s2212-5671(14)00565-6

Rubio, M. 2016. Short and long-term interest rates and the effectiveness of monetary and macroprudential policies, Journal of Macroeconomics 47: 103-115. http://dx.doi.org/10.1016/j.jmacro.2015.09.007

Sanfilippo-Azofra, S.; Torre-Olmo, B.; Cantero-Saiz, M. 2018. Financial development and the bank lending channel in developing countries, Journal of Macroeconomics 55: 215-234. http://dx.doi.org/10.1016/j.jmacro.2017.10.009

Sims, C.; Zha, T. 2006. Were there regime switches in US monetary policy?, American Economic Review 96(1): 54-81. http://dx.doi.org/10.1257/000282806776157678

Singh, C. 2006. Inflation targeting in India. Published by Indian Institute of Management.

Taylor, J. B. 1993. Discretion versus policy rules in practice, Carnegie-Rochester Series on Public Policy 39: 195-214. http://dx.doi.org/10.1016/0167-2231(93)90009-1

Taylor, J. B. 2001. The role of the exchange rate in monetary policy rules, American Economic Review 91(2): 263-267. http://dx.doi.org/10.1257/aer.91.2.263

Taylor, J. B. 2013. International monetary policy coordination: Past, present and future. Bank for International Settlements Working Paper No. 437. Retrieved from https://www.bis.org/publ/work437.htm

Tvaronavičienè, M. 2018. Toward efficient policy making: forecasts of vulnerability to external global threats, Journal of Security and Sustainability Issues 7(3): 591-600. https://doi.org/10.9770/jssi.2018.7.3(18)

Vasiljeva, M. 2017. The effect of dividend policy on company's market price per share, Journal of Applied Economic Sciences XII(4(50)): 995-1007. Retrieved from http://cesmaa.org/Docs/JAES\%20Summer\%20XII\%204(50)2017_online.pdf 


\section{ENTREPRENEURSHIP AND SUSTAINABILITY ISSUES}

ISSN 2345-0282 (online) http://jssidoi.org/jesi/ 2019 Volume 7 Number 1 (September)

http://doi.org/10.9770/jesi.2019.7.1(31)

Woglom, G. 2005. How has inflation targeting affected monetary policy in South Africa?, South African Journal of Economics 71(2): 198210. http://dx.doi.org/10.1111/j.1813-6982.2003.tb01314.x

Wulandari, R. 2012. Do credit channel and interest rate channel play important role in monetary transmission mechanism in Indonesia? A structural vector autoregression model, Procedia - Social Behavioral Sciences 65: 557-563. http://dx.doi.org/10.1016/j.sbspro.2012.11.165

Vladimir MASLENNIKOV is a Doctor of Economic Sciences, Professor, Vice-Rector for Research of the Financial University under the Government of the Russian Federation. Research interests: monetary policy, central banks activities, macroeconomic analysis and the banking system regulation, complex economic systems behavior.

ORCID ID: orcid.org/0000-0001-6199-9979

Dmitriy KOROVIN is a Doctor of Economic Sciences, Associate Professor, Professor of the Data Analysis, Decision Making and Financial Technologies Department of the Financial University under the Government of the Russian Federation. Research interests: mathematical modeling in economics, stochastic simulation, risk theory.

ORCID ID: orcid.org/0000-0001-9941-0322

Oxana AFANASYEVA is a Candidate of Economic Sciences, Associate Professor of the Financial Markets and Banks Department of the Financial University under the Government of the Russian Federation. Research interests: monetary policy, central banks activities, macroeconomic analysis and the banking sector regulation, credit.

ORCID ID: orcid.org/0000-0001-8949-2117

Register for an ORCID ID:

https://orcid.org/register

Copyright (C) 2019 by author(s) and VsI Entrepreneurship and Sustainability Center

This work is licensed under the Creative Commons Attribution International License (CC BY). http://creativecommons.org/licenses/by/4.0/

cC) (i) Open Access 